3 Poynard T, Marcellin P, Lee SS, et al. Randomised trial of interferon alpha2b plus ribavirin for 48 weeks or for 24 weeks versus interferon alpha2b plus placebo for 48 weeks for treatment of chronic infection with hepatitis C virus. International Hepatitis Interventional Therapy Group (IHIT). Lancet 1998;352:1426-32.

4 Benhamou Y, Bochet M, Di Martino V, et al. Liver fibrosis progression in human immunodeficiency virus and hepatitis $C$ virus coinfected patients. The Multivirc Group. Hepatology 1999;30:1054-8.

5 Darby SC, Ewart DW, Giangrande PL, et al. Mortality from liver cancer and liver disease in haemophilic men and boys in UK given blood products contaminated with hepatitis C. UK Haemophilia Centre Directors' Organisation. Lancet 1997;350:1425-31.

6 Telfer PT, Devereux H, Savage K, et al. Chronic hepatitis C virus infection in haemophilic patients: clinical significance of viral genotype. Thromb Haemost 1995;74:1259-64.

7 Soto B, Sanchez-Quijano A, Rodrigo L, et al. Human immunodeficiency virus infection modifies the natural history of chronic parenterally-acquired hepatitis $C$ with an unusually rapid progression to cirrhosis. F Hepatol 1997;26:1-5.

8 Lesens $\mathrm{O}$, Deschenes $\mathrm{M}$, Steben M, et al. Hepatitis $\mathrm{C}$ virus is related to progressive liver disease in human immunodeficiency virus-positive hemophiliacs and should be treated as an opportunistic infection. F Infect Dis 1999;179:1254-8.
9 Dragoni F, Cafolla A, Gentile G, et al. HIV-HCV RNA loads and liver failure in coinfected patients with coagulopathy. Haematologica 1999;84: 525-9.

10 Piroth L, Bourgeois C, Dantin S, et al. Hepatitis C virus (HCV) genotype does not appear to be a significant prognostic factor in HIV-HCVcoinfected patients. AIDS 1999;13:523-4.

11 Vogt MW, Hartshorn KL, Furman PA, et al. Ribavirin antagonizes the effect of azidothymidine on HIV replication. Science 1987;235:1376-9.

12 Sauleda S, Esteban JI, Altisent C, et al. Treatment with interferon plus ribavirin in anti-HIV negative patients with congenital coagulation disorders virin in anti-HIV negative patients with congenital coagul

13 Rivero J, Fraga M, Cancio I, et al. Long-term treatment with recombinant interferon alpha-2b prolongs survival of asymptomatic HIV-infected individuals. Biotherapy 1997;10:107-13.

14 Haas DW, Lavelle J, Nadler JP, et al. A randomized trial of interferon alpha therapy for HIV type 1 infection. AIDS Res Hum Retroviruses 2000;16:183-90.

15 Soriano V, Garcia-Samaniego J, Bravo R, et al. Interferon alpha for the treatment of chronic hepatitis $C$ in patients infected with human immunodeficiency virus. Hepatitis-HIV Spanish Study Group. Clin Infect Dis 1996; 23:585-91.

\section{Natural history of early gastric cancer}

This issue of Gut presents a paper from Osaka, Japan ${ }^{1}$ reporting the long term outcome of 71 patients diagnosed with early gastric cancer (EGC) before 1988, but who were not immediately operated on because of age, infirmity, or refusal (see page 618). Thirty six EGCs (51\%) progressed to advanced cancer. After exclusion for incomplete follow up, a Kaplan-Meier plot showed the likelihood of progression over five years to be $63 \%$. Thirty eight of the 71 patients were never operated on. Of these, $23(61 \%)$ died from gastric cancer. The Kaplan-Meier plot predicted a five year survival in this group ranging from 63 to $68 \%$ depending on the allocation of patients in whom the outcome was unknown.

This is an important paper because few studies have followed the natural history of early gastric cancer and it will be difficult to repeat in the future because of the development of endoscopic mucosal resection (EMR) which enables elderly and infirm patients with EGC to be effectively treated without recourse to major gastric surgery.

The conclusion drawn by the authors is that EGC is one step in an inevitable progression to advanced cancer and eventual death. The data, however, do not entirely support this view. Only $51 \%$ of the inception cohort were actually shown to have developed advanced cancer after a follow up period of more than 10 years. In those not operated on and where the true natural history can be deduced, only $23(61 \%)$ died from gastric cancer and the five year survival in this group was over $60 \%$. Furthermore, these values have to be interpreted with the knowledge that EGC can be reliably identified only on resected surgical or autopsy specimens. The authors accept that the accuracy of an EGC diagnosis at endoscopy is around $80 \%$, thus $20 \%$ of the inception cohort were likely to have harboured advanced stage cancer when recruited into the study. The implication of these data is that a significant minority of elderly or infirm patients diagnosed with EGC will, if left alone, die from something other than their gastric cancer. Parallels can be drawn with prostatic cancer, a condition that may remain dormant for a long period. What is less often appreciated is that certain melanomas behave in a similar manner. ${ }^{2}$ In situ cancer of the cervix often fails to progress ${ }^{3}$ and as many as $70 \%$ of breast neoplasms never develop into a clinically relevant disease. ${ }^{4}$ Premalignant colonic polyps have a long gestation period before showing invasive tendencies so it would be surprising if all EGCs were invasive from inception. It follows that the more effective a screening policy is in detecting very early lesions the less likely it is that the lesion has the potential to cause death.
The proportion of patients in Japan diagnosed with EGC is rising as a percentage of the gastric cancer load. This reflects the remarkable skill and considerable experience of Japanese endoscopists and also the investment that has been made in improving endoscopic technology. The proportion of EGC being detected at an even earlier stage is also rising with so called "gastritis like" cancer representing more than $50 \%$ of EGC in some units. ${ }^{5}$ This means that most cancers are identified before becoming ulcerated and implies that a greater proportion are at the intramucosal as opposed to the submucosal stage of development. These earlier cancers carry a better prognosis ${ }^{6}$ so it is possible that a higher proportion will take longer to progress and may be less clinically relevant in elderly patients.

What lessons can be drawn from this paper? Firstly, there can be no doubt that most early gastric cancers if not treated will eventually develop into advanced cancer and ultimately kill the patient. Secondly, a significant proportion of elderly patients with early gastric cancer will die of other diseases before their cancer becomes a clinical problem. There may be subtypes of EGC that do not progress or progress so slowly that even over a prolonged period they do not become invasive.

From a research perspective it is important to identify those factors that cause EGC to progress from a mucosal lesion to a submucosal lesion, local invasion, and metastasis. This information may enable us to develop strategies to prevent what is, at present, considered an inevitable process. From a practical clinical perspective, the data suggest that radical surgery is not necessarily the correct approach in all cases of endoscopically diagnosed EGC. We must follow the lead given by our Japanese colleagues in developing the technique of EMR which in suitable cases enables EGC to be removed in its entirety thus reducing the morbidity and mortality associated with radical surgery ${ }^{7}$ the treatment used in most of these cases at present.

A AXON

Centre for Digestive Diseases, General Infirmary at Leeds, Great George Street, Leeds LS1 3EX, UK

anthonya@ulth.northy.nhs.uk

1 Tsukuma $\mathrm{H}$, Oshima A, Narahara $\mathrm{H}$, et al. Natural history of early gastric cancer: a non-concurrent, long term, follow up study. Gut 2000;47:618-21. 2 Burton RC. Analysis of public education and the implications with regard to nonprogressive thin melanomas. Curr Opin Oncol 1995;7:170-4.

3 Raffle AE, Alden B, Mackenzie EFD. Detection rates for abnormal cervical smears: what are we screening for? Lancet 1995:345:1469-73.

4 Schmidt JG. The epidemiology of mass breast cancer screening - a plea for a valid measure of benefit. F Clin Epidemiol 1990;43:215-25.

5 Yoshida S. Endoscopic diagnosis and treatment of early cancer in the alimentary tract. Digestion 1998;59:502-8.

6 Everett SM, Axon ATR. Early gastric cancer in Europe. Gut 1997;41:142-50.

7 Ono H, Kondo H, Gotoda T, et al. Endoscopic mucosal resection for treatment of early gastric cancer. Gut 2000 (in press). 